\title{
Fathers and Gender Traditionalism: Perception of Inequality and Life Roles
}

\author{
Consuelo Paterna and Carmen Martínez \\ Universidad de Murcia
}

\begin{abstract}
Men's discourse about the paternal role is changing significantly. Despite the fact that men still perceive themselves as being responsible for the family's economical protection and the children's discipline, they face increasing demands for more involvement in childcare. From this perspective, this work analyzes the traditional view of gender roles and the perception of inequality in a sample of 95 employed fathers, as well as the various levels of satisfaction with other life roles and their relevance as a function of some gender and sociodemographic variables. The results show that men do not maintain a very traditional gender ideology with regard to role distribution and they still consider the paternal role and feelings as the most important thing in their lives. However, the couple relationship gives them the most satisfaction. Level of traditionalism and age were the two significant predicting variables of perception of inequality of men and women.

Keywords: gender roles, paternity, satisfaction, work, family
\end{abstract}

\begin{abstract}
El discurso de los hombres sobre el rol paternal está cambiando significativamente, pues aunque todavía se perciben como responsables de la protección económica de la familia y disciplina de los hijos, también se les exige mayor compromiso en el cuidado de éstos. Desde esta perspectiva este trabajo analiza la visión tradicional de los roles de género y la percepción de desigualdad en una muestra de 95 padres con empleo, así como los diferentes niveles de satisfacción con otros roles vitales y su relevancia en función de ciertas variables de género y sociodemográficas. Los resultados muestran que los hombres no mantienen una ideología de género demasiado tradicional respecto de la distribución de roles y siguen considerando el sentimiento y rol paternal como lo más relevante en sus vidas. Sin embargo es la relación de pareja lo que mayor satisfacción les produce. El grado de tradicionalismo y la edad son las dos variables predictoras significativas de la percepción de desigualdad entre hombres y mujeres.

Palabras clave: roles de género, paternidad, satisfacción, trabajo, familia
\end{abstract}

Correspondence concerning this article should be addressed to Consuelo Paterna Bleda. Facultad de Psicología, Área de Psicología Social, 30100 Campus de Espinardo, Murcia (Spain). Phone: 968-363974. Fax: 968-364115. E-mail: pater@um.es

Translation: Virginia Navascués Howard 
Interest in the father figure has recently increased significantly, both with regard to children's development and to the comparison established with women's' dedication to childcare (Geiger, 1996; Lamb, 1997; LaRossa, 1997; Parke \& Brott, 1999). As soon as this comparison is made, men and women tend to renegotiate the responsibilities and time devoted to childcare, and the concept of the paternal role acquires a new nuance.

This new concept of the paternal role tends to require men to organize their professional life as a function of their children (Elvin-Nowak, 1999) and to demand a definition of the cultural models of paternity based on a new role distribution in private life, with the aim of promoting everyone's autonomy, apart from the child (CastelainMeunier, 2002). However, research has revealed that men still condition their family responsibilities as a function of their work demands (Ranson, 2001).

This new viewpoint of paternity began with the changes in the traditional view of maternity. At the same time, it depended on the analysis of the construction of the father's role, that is, on gender socialization (Lamb, 1997; Mackey, 2001) and on the current dynamics of men-women relationships (Castelain-Meunier, 2002). In contrast, these changes could show how men's discourse about the paternal role is based on its comparison with the mothers' role of children's care-giver. As a consequence of this process of comparison, society is beginning to admit that men could take over the responsibility of childcare, the same as women, and they could acquire the same qualities and skills that women have for performing this task.

As a consequence of men's wish to participate more frequently and with more quality in their children's education, a change in the traditional gender role is expected, although at the same time, this generates some ambivalence and complexity. But, according to Castelain-Meunier (2002), in order for this change to come about, the definition of the father's role should take the private sphere as its reference point.

Starting with this framework, men assume that they should rebuild the concept of masculinity and abandon traditional, socially prescribed norms. However, despite the fact that the dominant discourse calls for fathers' increased involvement in childcare to achieve a better emotional relationship (Dienhart, 1998), some studies reveal that this discourse is contradictory. As shown by Brownson and Gilbert (2002), men still define themselves by traditional gender roles at work and they perceive themselves as being responsible for their families' economic protection and their children's discipline. In addition, people still make claims about men's incompetence and their lack of skills for childcare (Parke \& Brott, 1999). From this, we deduce that the new father may simply be a cultural image (Ranson, 2001) whose meaning is to meet expectations of work roles and family roles (Pleck, 1987). As stated by Levant and
Pollack (1995), to violate or destroy the traditional image of what being a man means implies that men must do housework, take care of the children, and express their most intimate feelings frequently. When all is said and done, this is acknowledged in a discourse that reflects the fact that the traditional image of masculinity means that men are missing out on something and that in order to rebuild this image of masculinity based on the paternal role, the essentialist viewpoint of the gender role identity must be analyzed (Pleck, 1981).

When reviewing the studies on traditionalism of gender ideology, the importance of the results about paternal involvement and role distribution is noteworthy. For example, there are data that reveal that fathers with a less traditional outlook on gender roles, who work full-timeas do their wives-participate more in daily childcare (Barnett \& Rivers, 1996; Aldous, Mulligan, \& Bjarnason, 1998). Moreover, men value family roles more than they do work roles (Barnett, Marshall, \& Pleck, 1992). Likewise, there is empirical evidence that men who have not built their masculine identity traditionally (they have fewer gender stereotypes and the gender roles are not established) perceive themselves as more receptive and sensitive to gender equality issues and they attribute to themselves as many masculine as feminine traits, even traits typically attributed to women (Wade \& Brittan-Powell, 2001). Consequently, they report fewer problems in their differentiation process and they have a more highly developed sense of self in the context of relationships; hence, they express their emotions more (Blazina \& Watkins, 2000). These results support the hypothesis stating that sex role attitudes are related to paternal participation (Deutsch, Lussier, \& Servis, 1993). However, in the case of women, the analysis of gender ideology (traditionalism) has not always been a good predictor of maternal involvement (Bulanda, 2004).

In contrast, the level of traditionalism and other intrapersonal variables as determinants of the perception of justice in the distribution of gender roles (housework and childcare) has also been analyzed (Kluwer \& Mikula, 2002). Such a perception would lead to some level of personal dissatisfaction and to conflicts at work and in the family. Specifically, the division of housework and childcare tends to be perceived as unjust as a function of gender ideology traditionalism and the couple's personal situation concerning the number of children, their ages, and the differences between the couple members in their respective jobs outside the home (DeMaris \& Longmore, 1996). However, some studies have not found this significant correlation between traditionalism and perception of inequality (Lennon \& Rosenfield, 1994). But most works have been able to corroborate that this perception of injustice or inequality is much more important for women than for men (Kluwer \& Mikula). 
Concerning determinant sociodemographic variables in the perception of inequality, it has been observed that younger people with a higher educational level perceive the unequal and unfair division of housework among men and women more than do older people with less education (DeMaris \& Longmore, 1996; Lennon \& Rosenfield, 1994).

Starting with Lennon and Rosenfield's (1994) work and a large part of the literature on gender concerning the changes in the conceptions of maternity and paternity and the way they are being re-elaborated (Elvin-Nowak, 1999), the aim of this study is to analyze the degree of fathers' traditionalism regarding gender roles and their relation with some sociodemographic variables such as age, the number of children, educational level, or religious and political ideology. At the same time, the perception of inequality between men and women and the importance assigned to some vital roles is analyzed.

The working hypothesis is that a significant relation between the perception of inequality and degree of traditionalism can be expected. Specifically, we posit that the perception of inequality in the role distribution of men and women will increase as the degree of traditionalism in gender roles decreases. Likewise, the variable traditionalism will be related to age, number of children, educational level, religion, and political ideology.

\section{Method}

\section{Participants}

Ninety-five fathers employed in the service sector (51.25\% as follows: $8.75 \%$ in educational centers, $2.5 \%$ in health centers, $16.25 \%$ in administrative posts, and $23.75 \%$ in business), in industry (43.19\%), and in building (5.57\%) participated in this study. Concerning educational level, $45 \%$ reported having primary studies, $37.5 \%$ had middle studies, and $17.5 \%$ had university degrees. Mean age was 42 years $(S D=9.92)$, and the average number of children was two.

\section{Instruments}

The questionnaire used to measure gender roles was elaborated based on the gender role questionnaire used in a previous study with mothers (Paterna \& Martínez, 2001, 2003), whose alpha coefficient was .75. The instrument is made up of 24 Likert-type formatted items with responses ranging from 1 (totally disagree) to 7 (totally agree). The variables that make up the questionnaire and their reliability coefficients are described below:

1. Sociodemographic and socio-work variables: age, number of children, civil status, educational level, religious beliefs, political view, and the work sector and activity carried out, and working schedule.

2. Traditional gender roles (or traditionalism): a 9-item measure whose content refers to men's attitude towards housework, childcare, and the economic maintenance of the children. In some items, a comparison is established with women about who is the most suitable to carry out these roles (see Annex). A high score in this variable means high traditionalism in gender roles (see item inversion in the Annex). The reliability coefficient was .78 .

3. Paternal feelings: this variable was measured with 9 items that collect men's opinions about the sacrifice involved in their paternity, and the level of fulfillment and satisfaction it provides. High scores indicate strong paternal feelings. It obtained al alpha coefficient of .51 .

4. Perception of inequality: made up of 6 items that measure the perception of inequality between men and women, both at work and at home. Also included are attitudes about hiring men rather than women of a child-bearing age and women giving up working outside the home. High scores in this variable indicate a low perception of inequality. Its reliability coefficient was .62.

5. Work centrality: this variable is measured with 6 items that reflect contents such as the importance of work for the development of social relations and personal accomplishment, as well as the perception of work as a priority value and a means to achieve higher economic status and more pleasure. High scores correspond to high centrality. The reliability coefficient was. 62.

6. Life roles: To appraise the degree of satisfaction with life roles (partner, job, housework, leisure, friends, and children), participants were asked to rate each one of them on a scale ranging from 1 (minimum satisfaction) to 7 (maximum satisfaction). They were subsequently asked to rank the items as a function of the degree of importance they assigned to them.

\section{Procedure}

The items of each variable were presented alternately; that is, two items from the same variable were never presented together.

The questionnaires were handed in personally at the work centers mentioned in the Participants Section. Specifically, the questionnaires were handed in to the center directors, service managers, personnel directors, and in the shops. These directors were briefly informed about the purpose of the study and they distributed the questionnaires to the workers and subsequently collected them. About 130 questionnaires were handed out and after about 15 days, a total of 95 were collected. Participation was voluntary; the only criterion was to be an employed father. 
Results

Descriptive Statistics, Correlations, and Mean Differences of the Variables Traditionalism, Paternal Feelings, Perception of Inequality, Work Centrality, and Satisfaction

Only two of the psychological variables analyzed obtained means above the scale mid-point, specifically, paternal feelings $(M=4.51, S D=.80)$ and work centrality $(M=4.45, S D=1.16)$. In contrast, as shown in Table 1 , role traditionalism $(M=3.55, S D=1.25)$ and perception of inequality ${ }^{l}$ were below the scale mid-point $(M=2.68, S D$ $=1.14$ ). This suggests that the fathers had strong paternal feelings, whilst their work was very important to them. In contrast, they perceived inequality between men and women, which leads us to think that they are beginning to be less traditional about the division of housework and childcare.

Means were compared with Student's $t$-test because, although two of the variables were asymmetrically distributed and were therefore not normal, as the sample size of both items was large $(n=95)$ and equal, the measure of discrepancy was approximately standard normal. Specifically, perception of inequality was skewed to the left (skewness $=.59$, kurtosis $=-.40$ ) and work centrality was skewed to the right (skewness $=-.42$, kurtosis $=.15$ ). The mean differences were statistically significant, except for the difference between paternal feelings and work centrality, which confirms that both variables are equally relevant.
The correlation analysis shows a significant correlation between traditionalism and the perception of inequality $(r$ $=.69, p<.01)$ and work centrality $(r=.34, p<.01)$. Likewise, the correlation between perception of inequality and work centrality $(r=.25, p<.05)$ was significant. However, paternal feelings had no relation with any of the variables analyzed (traditionalism, perception of inequality and work centrality).

The analysis of frequencies and percentiles of each variable is important because it provides much more detailed data about the fathers' perception of them. For example, regarding traditionalism, $75 \%$ of the sample scored below 4.5. However, in the variable paternal feelings, almost $75 \%$ of the sample scored 4 or over on the scale, and no participant obtained the lowest scores of this variable (values of 1 and 2). In work centrality, we found a similar situation: $75 \%$ of the subjects scored 4 or over, with the difference that the remaining $25 \%$ obtained scores among the three lowest values of the scale. Lastly, in contrast to the other variables, in perception of inequality, we observed that $80 \%$ of the sample was situated below the mid-point of the scale, that is, the great majority perceived this inequality and no individuals scored above the value 5 of the scale.

When analyzing some item means, we observed that, in the variable traditionalism, the items with the lowest mean (a value of 2 on the scale) indicate, for example, that men do not believe that to devote oneself only to housework and childcare would be degrading for a man, or that

Table 1

Means, Standard Deviations, Student's t, and Correlations for Related Samples

\begin{tabular}{lccc}
\hline Variables (in pairs) & $M$ & $S D$ & $t$ \\
\hline Role Traditionalism & 3.55 & 1.25 & $-5.41^{* * *}$ \\
Paternal feelings & 4.51 & .80 & $7.56^{* * *}$ \\
Role Traditionalism & & 1.14 & -.006 \\
Inequality & 2.68 & & $-6.18^{* * *}$ \\
Role Traditionalism & & 1.16 & $.694^{* *}$ \\
Work Centrality & 4.45 & & $9.83^{* * *}$ \\
Paternal feelings & & & $.345^{* *}$ \\
Inequality & & & .22 \\
Paternal feelings & & & .125 \\
Work Centrality & & $-11.58^{* * *}$ \\
Inequality & & & $.259^{*}$ \\
Work Centrality & & & \\
\hline
\end{tabular}

$* p<.05 . * * p<.01 . * * * p<.001$.

1 It must be taken into account that, in this variable, a low score indicates high perception of inequality. 
discipline and order is only the father's responsibility. The items with the highest scores show that men agree very much with the fact that children change women's lives much more than men's, while they state that women know better how to care for children and that children need their mother's care much more than their father's. That is, the fathers would be willing to devote themselves to the family but the women still do this better and are needed more by the children.

Regarding the items that make up the variable paternal feelings, we observed that the items with the lowest means (between values 2 and 3 on the scale) indicate that men go on transmitting the value of paternity to their children. Nevertheless, the decision not to have children is no longer disapproved, as it is no longer considered essential to be a father in order to feel fulfilled as a man. However, men very much agree that a father should do everything for his children (an item whose score was 5.92, the maximum score), and they believe that children are the greatest satisfaction a man can have, despite the sacrifice that their education involves. For men, paternal feelings are natural, one is born with them $(M=5.04)$.

The analysis of the items of the variable perception of inequality indicates that men do not agree that men should be preferably hired instead of women of childbearing age. Nor do they believe that a woman should give up her work because she is a mother, because having access to work has been essential for women's liberation. In contrast, the item with the highest mean was the one that states that men and women should share housework and childcare equally $(M=5.9)$.

Concerning the variable work centrality, all the items show means higher than the value 4 , reflecting considerable agreement about the perception of employment as a means of personal accomplishment, achieving happiness, extending social relations, and reaching a higher economic level (the item with the highest mean, $M=5.82$ ). However, the fathers also said that they know perfectly well how to use their leisure time, that is, work is not perceived as a way of avoiding boredom.

\section{Level of Satisfaction with Roles and Their Ranking}

The study of these variables shows that the couple role produces the most satisfaction $(M=6.57, S D=.79)$, very close to the means of satisfaction with children $(M=6.49$, $S D=.85$ ), but these differences were not significant (see Table 2). The next roles with a high level of satisfaction were leisure $(M=5.75, S D=1.38)$ and friends $(M=5.57$, $S D=1.29)$, with no significant mean differences. Work outside the home was the fifth role in level of satisfaction $(M=5.06, S D=1.57)$. And lastly came domestic roles, whose level of satisfaction was the lowest $(M=3.51, S D$ $=1.69$ ). Except for the aforementioned differences (couplechildren and leisure-friends), the rest of the mean differences were significant (see Table 2).

By means of the ranking analysis, we attempted to determine the percentage of individuals who places each role in a certain position. For this purpose, we performed Friedman's $\chi^{2}$ non-parametric analysis of variance. This analysis yielded significant differences regarding the mean rankings of the different levels $\left(\chi^{2}(5)=299.58, p \leq .001\right)$. When observing Table 3, it can be seen that the role situated in first place of importance is that of the couple (mean range 1.6), followed by children (1.76), work (3.83), friends (4.12), leisure (4.44), and housework (mean range 5.27).

With regard to the percentages, $54.3 \%$ considered the couple role the most important. A large percentage, specifically $53.2 \%$, ranked the children as second. Both roles, couple and children, were placed in the first or second position of importance by $90 \%$ of the sample. Work was ranked third by the largest number of persons. And friends and leisure were the roles more frequently ranked fourth and fifth in relevance, leaving housework as the role par excellence with the highest number of persons who placed it in the last and sixth position.

We would like to note that the role that produces the most satisfaction is not always the one that is the most relevant for individuals. Although the levels of satisfaction with the couple, the children, and housework coincided in their mean positions of relevance (first, second, and sixth),

Table 2

Means, Standard Deviations, and Differences (along the Diagonal) in the Levels of Satisfaction with the Diverse Roles

\begin{tabular}{|c|c|c|c|c|c|c|c|}
\hline \multirow{2}{*}{ Variables } & \multirow{2}{*}{$M$} & \multirow{2}{*}{$S D$} & \multicolumn{5}{|c|}{$t$} \\
\hline & & & 1 & 2 & 3 & 4 & 5 \\
\hline 1. Work & 5.06 & 1.57 & & & & & \\
\hline 2. Housework & 3.51 & 1.69 & $6.12 * * *$ & & & & \\
\hline 3. Friends & 5.57 & 1.29 & $-2.41 * *$ & $-9.61 * * *$ & & & \\
\hline 4. Leisure & 5.75 & 1.38 & $-3.36 * * *$ & $-10.06^{* * *}$ & -1.22 & & \\
\hline 5. Partner & 6.57 & .79 & $-8.32 * * *$ & $-16.74 * * *$ & $-8.16^{* * *}$ & $5.40 * * *$ & \\
\hline 6. Children & 6.49 & .85 & $-8.00 * * *$ & $-15.30^{* * *}$ & $-7.72 * * *$ & $5.32 * * *$ & -.79 \\
\hline
\end{tabular}

$* * p<.01 . * * * p<.001$. 
Table 3

Mean Range and Percentages of the Importance of Roles

\begin{tabular}{|c|c|c|c|c|c|c|}
\hline \multirow{2}{*}{ Ranking } & \multicolumn{6}{|c|}{ Roles } \\
\hline & Work & Housework & Leisure & Friends & Partner & Children \\
\hline $\begin{array}{l}\text { Mean range } \\
(1-6)\end{array}$ & 3.83 & 5.27 & 4.44 & 4.12 & 1.6 & 1.76 \\
\hline First place $(\%)$ & 6.4 & 0 & 2.1 & 0 & $54.3^{*}$ & 37.2 \\
\hline Second place $(\%)$ & 4.3 & 1.1 & 0 & 4.3 & 37.2 & $53.2 *$ \\
\hline Third place $(\%)$ & $39.4^{*}$ & 2.1 & 21.3 & 25.5 & 4.3 & 7.4 \\
\hline Fourth place $(\%)$ & 12.8 & 20.2 & 28.7 & $34^{*}$ & 3.2 & 1.1 \\
\hline Fifth place $(\%)$ & 24.5 & 22.3 & 24.5 & $26.3^{*}$ & 1.1 & 1.1 \\
\hline Sixth place $(\%)$ & 12.8 & $54.3^{*}$ & 23.4 & 9.6 & 0 & 0 \\
\hline
\end{tabular}

*The highest percentage of subjects that ranked this role in this place of importance.

this did not occur with the work role, which appeared in fifth place for level of satisfaction but in third place for relevance.

\section{Relevance of the Sociodemographic Variables over the Psychological Variables ${ }^{2}$}

Differences as a function of age. The one-factor ANOVA with three groups (25-35 years; 36-45 years; older than 45 years) yielded significant differences as a function of age for the variables of role traditionalism, $F(2,89)=4.93, p<.01$, and perception of inequality, $F(2,88)=8.10, p<.001$. Specifically, in traditionalism, the post-hoc analyses (Tukey's $T$ test) indicated that the differences were between the men under and over 35 years of age $(M=3.21, S D=1.3, p<.01$ for the first group; $M=3.3, S D=1.14, p<.05$ for the second one; $M=4.13, S D=1.34$ for the third group). Whereas in the variable perception of inequality (Dunnet's T3), the significant differences appeared between the first $(M=2.14$, $S D=.86)$ and third group $(M=3.23, S D=1.3, p<.001)$. This means that men over 45 years old, in contrast to men of less than 35 , express more frequently that there is no gender inequality in either of the two settings, work and family.

Differences as a function of the number of children. The one-factor ANOVA with three levels (one child, two children, three or more children) conducted on the four psychological variables revealed significant differences in traditionalism, $F(2,89)=5.76, p<.01$, and paternal feelings, $F(2,70)=$ $8.23, p<.001$. Specifically, post-hoc comparisons (Dunnet's T3 test) indicated that fathers of one child are less traditional $(M=2.85, S D=1.24)$ than fathers of two children $(M=$ $3.82, S D=1.02, p<.01)$ or than fathers of more than two children $(M=3.85, S D=1.51, p<.05)$. With regard to paternal feelings, they were significantly higher in men who had three or more children $(M=5, S D=.82)$ as compared with fathers of two children $(M=4.12, S D=.77, p<.001)$. However, there were no differences with fathers of one child $(M=4.6, S D=.70)$.

Differences as a function of educational level. The onefactor ANOVA with three levels (primary studies, middle studies, university studies) showed that the level of studies is related to the three variables analyzed: traditionalism, $F(2,88)$ $=5.37, p<.001$, perception of inequality, $F(2,87)=3.34, p$ $<.05$ and work centrality, $\mathrm{F}(2,89)=4.15, p<.01$. Paternal feelings were not related to educational level. Regarding traditionalism, the post-hoc tests (Dunnet's T3) showed that, the men with primary studies were more traditional than those with university studies $(M=3.99, S D=1.31$ and $M=2.89$, $S D=1.29$, respectively, $p<.01)$. Concerning inequality, it was noted that men with primary studies perceived inequality $(M=3, S D=1.22)$ less than men with middle studies $(M=$ $2.45, S D=.98, p<.05)$ and with university studies $(M=2.33$, $S D=.98, \mathrm{p}<.05)$. Lastly, in the variable work centrality, for men with primary studies, work was more important than for those who had university studies $(M=4.75, S D=1.01$ and $M$ $=3.85, S D=1.43$, respectively, $p<.05)$.

Differences as a function of religion. The one-factor ANOVA with four levels (nonbelievers, nonpracticing believers, believers who practiced only a little, practicing believers) yielded significant differences among the groups only in the variable traditionalism of gender roles, $F(3,87)$ $=3.48, p<.01$. By means of Tukey's $T$ test, we observed that the difference was between those who described themselves as nonpracticing believers $(M=3.23, S D=1.2)$ and those who considered themselves to be believers who practiced only a little $(M=4.09, S D=1.08)$. The lack of significant differences between the group of nonbelievers

\footnotetext{
2 Tukey's T test was used in the post-hoc comparisons after previously verifying, by means of Levene's statistic, that the assumption of homogeneity of variance was met $(p>.05)$ and the $F$ was significant, whereas Dunnet's T3 test was used as recommended in the contrasts for non homogeneous variances and small sample sizes.
} 
$(M=3.16, S D=1.45)$ and the little practicing believers and the practicing believers $(M=4.07, S D=1.47)$ may be due to the sample size (there were few subjects at both extremes, nonbelievers and practicing believers) ${ }^{3}$.

Differences as a function of political ideology. The onefactor ANOVA with three levels (apolitical, left-wing and center-left, right-wing and center-right) yielded significant differences among the groups of different political ideology for the variable traditionalism, $F(2,87)=7.87, p<.001$. Tukey's post-hoc $T$ test showed that the differences were between those who described themselves as apolitical $(M=$ $3.23, S D=1.33)$ and the left-wing group $(M=3.13, S D=$ $1.23)$ in contrast to the right-wing group $(M=4.23, S D=$ $1.13, p<.01)$. In the variable work centrality, $F(2,88)=$ $3.64, p<.05$, there were only significant differences between the left-wing group $(M=4.05, S D=1.19)$ and the right-wing group $(M=4.78, S D=.90, p<.01)$. To sum up, individuals from right-wing ideology are significantly more traditional in gender roles than both the left-wing and the apolitical individuals, and they also consider work much more central to their lives than do individuals from the left-wing group.

\section{Predictors of the Perception of Inequality and Traditionalism}

In order to verify the predictive value of the psychological variables in the perception of inequality, we performed a hierarchical regression analysis, introducing in a first block the variables traditionalism, paternal feelings, and work centrality, and in a second block, the sociodemographic variables (age, educational level, number of children, religion, political beliefs). As shown in Table 4 , both in the first stage, $R^{2}=.46, F(3,61)=19.44, p<$ .001 , and in the second stage, $R^{2}=.52, F(8,64)=9.75$, $p<.001$, we found relevant predictor variables whose final equation accounted for $54 \%$ of the variance of perception of inequality. The principal and only predictor in the first stage was traditionalism $(\beta=.68)$, whereas in the second stage, the variable included in the model was age $(\beta=.32)$. The tolerance values $(>.70)$ of the predictor variables indicated that there were no multicollinearity problems, thus meeting the assumption of independence among these variables.

Table 4

Beta Coefficients of the Predictor Variables of the Perception of Inequality and Role Traditionalism

\begin{tabular}{lccc}
\hline Predictor Variables & $\beta$ & $R^{2}$ & Adjusted $^{2}$ \\
& & Criterion Variable: Perception of Inequality $^{\mathrm{a}}$ \\
\cline { 2 - 4 } Model 1 & $.68^{* * *}$ & .49 & .46 \\
Role Traditionalism & -.14 & & .01 \\
Paternal feelings & .01 & & \\
Work centrality & &
\end{tabular}

Model 2

$\begin{array}{lc}\text { Role Traditionalism } & .66^{* * *} \\ \text { Paternal feelings } & -.07 \\ \text { Work centrality } & -.04 \\ \text { Age } & .32^{* *} \\ \text { Number of children } & -.16 \\ \text { Educational level } & -.15 \\ \text { Religious level } & -.12 \\ \text { Political ideology } & -.03\end{array}$

\begin{tabular}{lccc}
\hline & \multicolumn{3}{c}{ Criterion Variable: Role Traditionalism ${ }^{\mathrm{b}}$} \\
\cline { 2 - 3 } Educational level & $-.37^{* * *}$ & .12 & .11 \\
Religious level & $.28^{* *}$ & .22 & .21 \\
Age & $.21^{*}$ & .27 & .24 \\
\hline
\end{tabular}

Note. ${ }^{\mathrm{a}} n=64 .{ }^{\mathrm{b}} n=89$.

$* p<.05 . * * p<.01 . * * * p<.001$.

3 The $n$ for each group was: 20 for non believers, 37 for non practicing believers, 25 for believers who practiced only a little, and 9 for practicing believers. 
In an attempt to determine the best predictors of traditionalism, we conducted a stepwise regression analysis in which we included as predictor variables the sociodemographic variables. In this case, the model was also significant, $R^{2}=.24, F(3,89)=10.73, p<.001$, with the variables educational level $(\beta=-.37)$, religious beliefs $(\beta=.28)$, and age $(\beta=.21)$ being statistically significant.

\section{Conclusions}

The aim of this study was to analyze the degree of men's' traditionalism and to determine whether there has been a change in their perception of traditional gender roles and of inequality in the distribution of these roles, as indicated by Parke and Brott (1999). It appears that men are more inclined to devote themselves more to their family and to accept that they can-just like women-acquire the skills and abilities for housework and childcare. This was also acknowledged in a study with mothers (Paterna \& Martínez, 2001). Nevertheless, and according to the results obtained by Castelain-Meunier (2002), men believe that women have better childcare skills. Hence, they say that women's lives change much more than men's when children are born; this opinion coincides with the one expressed by women in a previous study (Paterna \& Martínez).

This change in the acceptance that domestic roles and maintenance and discipline are not exclusively the mother's or the father's, respectively, allows us to see the discourse about the problems that emerge when combining both kinds of roles and the need for men's higher emotional involvement (Brownson \& Gilbert, 2002; Dienhart, 1998; Pleck, 1987). That is, men express strong paternal feelings, a large number of men do not display excessively traditional gender roles, and they still consider their work to be highly central. On the one hand, the most satisfactory and most important roles are the couple in the first place and the children in second place, with no significant differences between them. This result is similar to the one found in a study with mothers (Martínez, Vera, Paterna, \& Rosa, 2002), except that the mothers ranked the maternal role as first. That is, whereas $35 \%$ of the men ranked the children in first place, this percentage rose to $64 \%$ in the case of the mothers. And whereas $53 \%$ of the men ranked the couple in first place, only $24 \%$ of the mothers did likewise. But both men and women coincide in ranking the couple and the children between the first and second place in importance. Nevertheless, men still grant more relevance to work than do women, as it is ranked as third in importance with respect to the remaining roles, and whereas $39 \%$ of the men ranked work as third, only $25 \%$ of the women did likewise.

Regarding the importance of age in the degree of traditionalism, we conclude that the younger men (under 45 years) are the least traditional, whereas only the men younger than 35 years perceived gender inequality. However, it seems that age has no relation either to paternal feelings or to work centrality, as shown by Barnett, Marshall, and Pleck (1992). In the studies with women (Martínez et al., 2002; Paterna \& Martínez, 2003) no relation was found between age and work centrality, but that same age range (up to 45 years) delimited a change in the more conservative ideas of gender roles.

With regard to the number of children, we found that having only one child or having more children differentiated the fathers' traditionalism, the same as occurred with the mothers (Paterna \& Martínez, 2003). The women who had just one child were more progressive. Paternal feelings were much more significant in men with three or four children, in comparison to men with two children. That is, paternal feelings are not significant among fathers who have one to three children, but the degree of traditionalism is significantly different as a function of having one or more children.

As expected, the men with lower educational level are more traditional and perceive less inequality, as found by DeMaris and Longmore (1996), with work being more relevant for them than for individuals with university studies.

The same could be said regarding political ideology: the individuals who described themselves as right-wing are classified as more traditional than left-wing individuals, and they also score higher in work centrality.

A noteworthy conclusion, given that it was one of the relevant aims of the study, is the significant relation between the degree of traditionalism, age, and perception of inequality, as found by Wade and Britan-Powell (2001), with the degree of traditionalism mediated by the educational level, religious beliefs, and age.

As mentioned in the introduction, the data of the study reveal an important aspect in the advance of gender studies: the concept of the paternal role is changing. In the sense that fathers wish for higher involvement in childcare, with the younger fathers with certain cultural, political and religious ideologies being the ones who are most likely to change the degree of traditionalism of gender roles and, therefore, the ones who will assume this paternal role and will perceive the existing gender inequalities.

On the other hand, we can also conclude as an important result of the study the fact that the variable perception of inequality maintains a significant relation with the level of traditionalism of gender roles; thus, it becomes a crucial variable in the change of gender relationships. Some studies report (Kluwer \& Mikula, 2002) that the perception of inequality is a significant antecedent for changing one's dedication to housework and childcare. In that case, it is of increasing interest to continue to analyze the relation between this perception and the degree of traditionalism-as well as that found between traditionalism and certain sociodemographic characteristics - so as conclude, for example, that variables such as work centrality or paternal feelings have no relation to this perception of injustice or inequality. In short, being more or less traditional and the mediating variables of the degree of traditionalism constitute a crucial point for subsequent 
analyses and to be able to find conclusive data about their possible modification, and influence in the change of gender roles. But perhaps, the most important contribution of these studies is to continue to introduce the variable perception of inequality or injustice in the area of social psychology so it can continue to be considered a fundamental piece in the advance of gender equality relations.

However, the change in meanings or attitudes does not signify a behavioral change. Therefore, we underline that one of the limitations of this study is the fact of not having measured behaviors that reflect the change of perceptions and attitudes that men have shown towards the division of gender roles. This is important because the studies show that, despite this change in the degree of traditionalism and the paternal role, the real involvement in participation does not reflect that change. Therefore, it is necessary to study attitudes and behavior conjointly in order to have a truer and more global view of the problem.

Likewise, the measures of paternal feelings and perception of inequality should be improved to achieve slightly higher reliability coefficients.

Faced with this context of change, it is obvious that men and women must renegotiate what paternity is and how to exercise it (Pollack, 1995).And for that renegotiation, the men must review their concept of masculinity and their practice in daily interactions (Wetherell \& Edley, 1999), which will depend on the series of prescriptive social norms, represented symbolically, that comprise the structure of the social world (Connell, 1987, 1995). This leads to the need to study in more detail the analysis of this symbolic world and its relation to daily life. And also to take another look at proposals like that of Chopra (2001) about how these representations of masculinity should include the father role as his children's care-giver, and be reflected both in the discourse of maternity as in gender studies. That is, the feminist discourse should contemplate, relevantly and with interest, the analysis of the new masculinities, beginning to admit that care-giving is not women's exclusive domain, as this would mean closing off all prospects of change in gender identities.

In contrast, as posited by Pollack (1995), in this renegotiation of the paternal role, men need the women to acknowledge that they, the men, are just as capable as women of childcare and that they consider paternity a complement of maternity. The consequence would be that men would perceive paternity as a highly valued emotional situation.

Concerning future research, there should be more studies that analyze the implications in men's work setting of their assuming more family responsibilities, as well as the change in their notion of public-private, as women have done and are doing when facing this dichotomy (Ranson, 2001). For this purpose, more studies are needed of the variables that can explain men's contribution to housework and childcare, and other situations of the work context that would preclude or facilitate this availability (Barnett, Marshall \& Pleck, 1992; Presser, 1994; Arrighi \& Maume, 2000).

\section{References}

Aldous, J., Mulligan, G.M., \& Bjarnason, T. (1998). Fathering over time: What makes the difference? Journal of Marriage and the Family, 60, 809-820.

Arrighi, B.A., \& Maume, D.J. (2000). Workplace subordination and men's avoidance of housework. Journal of Family Issues, 21, 464-487.

Barnett, R.C., Marshall, N.L., \& Pleck, J.H. (1992). Men's multiple roles and their relationship to men's psychological distress. Journal of Marriage and the Family, 54, 358-367.

Barnett, R.C., \& Rivers, C. (1996). She works/he works: How twoincome families are happier, healthier, and better off. New York: Harper Collins.

Blazina, Ch., \& Watkins, C.E. (2000). Separation/Individuation, parental attachment, and male gender role conflict: Attitudes toward the feminine and the fragile masculine self. Psychology of Men and Masculinity, 1, 1126-132.

Brownson, Ch., \& Gilbert, L.A. (2002). The development of the discourses about fathers' inventory: Measuring fathers' perceptions of their exposure to discourses. Psychology of Men and Masculinity, 3, 85-96.

Bulanda, R.E. (2004). Paternal involvement with children: The influence of gender ideologies. Journal of Marriage and Family, $66,40-45$.

Castelain-Meunier, Ch. (2002). The place of fatherhood and the parental role: Tensions, ambivalence and contradictions. Current Sociology, 50, 185-201.

Chopra, R. (2001). Gender studies, "father love" and the discourse of mothering. Women's Studies International Forum, 24, 4455455.

Connell, R.W. (1987). Gender and power. Oxford: Polity Press.

Connell, R.W. (1995). Masculinities. Berkeley, CA: University of California Press.

DeMaris, A., \& Longmore, M.A. (1996). Ideology, power, and equity: Testing competing explanations for the perception of fairness in household labour. Social Forces, 74, 10431071.

Deutsch, F.M., Lussier, J.B., \& Servis, L.J. (1993). Husbands at home: Predictors of paternal participation in childcare and housework. Journal of Personality and Social Psychology, 65, 1154-1166.

Dienhart, A. (1998). Reshaping fatherhood: The social construction of shared parenting. Thousand Oaks, CA: Sage.

Elvin-Nowak (1999). The meaning of guilt: A phenomenological description of women's everyday life experiences of guilt. Scandinavian Journal of Psychology, 40, 73-83.

Geiger, B. (1996). Fathers as primary caregivers. London: Greenwood Press.

Kluwer, E., \& Mikula, G. (2002). Gender-related inequalities in the division of family work in close relationships: A social psychological perspective. European Review of Social Psychology, 13, 185-216.

Lamb, M.F. (Ed.). (1997). The role of the father in child development ( $3^{\text {rd }}$ ed.). New York: Wiley. 
LaRossa, R. (1997). The modernization of fatherhood: A social and political history. Chicago: University of Chicago Press.

Lennon, M.C., \& Rosenfield, S. (1994). Relative fairness and the division housework: The importance of options. American Journal of Sociology, 100, 505-531.

Levant, R.F., \& Pollack, W.S. (Eds.). (1995). A new psychology of men. New York: Basic Books.

Mackey, W.C. (2001). Support for the existence of an independent man-to-child affiliative bond: Fatherhood as a biocultural invention. Psychology of Men and Masculinity, 2, 51-66.

Martínez, C., Vera, J.J., Paterna, C., \& Rosa, A. (2002). Antecedentes del conflicto interrol y su relación con el autoesquema de género. Anales de Psicología, 18, 305-317.

Paterna, C., \& Martínez, C. (2001). La posición de la mujer frente a los roles de género: familia versus empleo. Apuntes de Psicología, 19, 403-420.

Paterna, C., \& Martínez, C. (2003). Tradicionalismo de los roles maternales y la relevancia del trabajo. Intervención Psicosocial, 12, 83-93.

Parke, R.D., \& Brott, A.A. (1999). Throwaway dads: The myths and barriers that keep men from being the fathers they want to be. Boston: Houghton Mifflin.

Pleck, J.H. (1981). The myth of masculinity. Cambridge, MA: MIT Press.
Pleck, J.H. (1987). American fathering in historical perspective. In M.S. Kimmel (Ed.), Changing men: New directions in research on men and masculinity (pp. 83-97). Beverly Hills, CA: Sage.

Pollack, W.S. (1995). No man is an island: Toward a new psychoanalytic psychology of men. In R.F. Levant \& W.S. Pollack (Eds.), A new psychology of men (pp. 33-67). New York: Basic Books.

Presser, H.B. (1994). Employment schedules among dual-earner spouses and the division of household labor by gender. American Sociological Review, 59, 348-364.

Ranson, G. (2001). Men at work. Change-or no change? in the era of the "new father." Men and Masculinities, 4, 3-26.

Wade, J.C., \& Brittan-Powell, Ch. (2001). Men's attitudes toward race and gender equity: The importance of masculinity ideology, gender-related traits, and reference group identity dependence. Psychology of Men and Masculinity, 2, 42-50.

Wetherell, M., \& Edley, N. (1999). Negotiation hegemonic masculinity: Imaginary positions and psycho-discursive practices. Feminism and Psychology, 9, 335-356.

Received September 2, 2005

Review received June 2, 2006 Accepted June 7, 2006 


\section{Appendix}

\section{Role Traditionalism}

1. To devote oneself only to housework and childcare is degrading for a man

2. Children change a woman's life much more than they do a man's.

3. The father should take on the chief responsibility for the economic maintenance of his children.

4. A mother knows best how to care for and bring up her children.

5. I would disapprove if my son played with typical girls' toys.

6. When children are small, they need their mother's care more than their fathers'.

7. Men will never be able to do certain domestic tasks as well as or better than women.

8. Even if he would want to, a father can never take care of his children like a mother does.

9. The father is more responsible for discipline and order than is the mother.

\section{Paternal Feelings}

1. I would not inculcate my children with the idea of having children.*

2. A father should do everything for his children.

3. In my family environment, they would disapprove if I did not have children.

4. Having children is the greatest satisfaction a man can have.

5. Nowadays people have fewer children because it costs a lot to maintain them.*

6. Paternal feelings are natural in men; you're born with them.

7. A father feels satisfied sacrificing his own well-being for his children.

8. A man must be a father in order to feel fulfilled as a man.

9. Given the current world situation, I think it's irresponsible to have a lot of children.*

\section{Perception of Inequality}

1. Women are still treated worse than men at work.*

2. If the mother does not work outside the home, the inequality between the father and the mother in housework and childcare is justified.

3. Men and women should share housework and childcare equally.*

4. To prefer to hire men instead of women in childbearing age is fair.

5. It is logical for a woman to give up her work when she has children.

6. To have access to work has been essential for women's liberation.*

\section{Work Centrality}

1. Work is essential for my personal happiness.

2. My work allows me to express my aptitudes and to feel self-accomplished as a person.

3. My father taught me that work must come first.

4. For me, work is a means to achieve economic well-being and be able to enjoy life.

5. Thanks to my work, I could extend my circle of friends and acquaintances.

6. If I had no job, I don't know what I'd do to keep busy.

\footnotetext{
* Items that were inverted for scoring.
} 